\title{
Research
}

\section{Remote Sensing and Ethnobotanical Assessment of the Mangrove Forest Changes in the Navachiste-San Ignacio-Macapule Lagoon Complex, Sinaloa, Mexico}

\author{
$\underline{\text { Rubi Hernández Cornejo }}^{1}, \underline{\text { Nico Koedam }}^{2}, \underline{\text { Arturo Ruiz Luna }}^{1}, \underline{\text { Max Troell }}^{3}$, and Farid Dahdouh-Guebas ${ }^{2}$
}

\begin{abstract}
The present study focuses on the Navachiste-San Ignacio-Macapule lagoon complex in northwest Mexico and evaluates the spatiotemporal change in the mangrove area over the last three decades using Landsat MSS and TM imagery. Local ethnobotanical uses of the mangrove forest and local perceptions about the status and recent development of the mangrove forest cover are also analyzed. The results of interviews with 54 inhabitants of four fishing villages in the study area indicated that, overall, Laguncularia racemosa is the most frequently used species in this region of the Mexican Pacific coast, where it serves as firewood and a construction material, particularly for walls and fences. The next-ranked species were Avicennia germinans, which is used for tea, and Rhizophora mangle, which is used for tanning; both these species also serve medicinal purposes. There was a discrepancy between the assessment of actual changes in the mangrove cover and what people perceived them to be. These findings are discussed from a socioeconomic (utilization) and an ecological (functionality) point of view and in relation to the use of remote sensing as a tool. The utilization pattern is also discussed against the background of mangrove cover variation.
\end{abstract}

Key Words: mangrove; ethnobiology; remote sensing; time series; Thematic Mapper; Multi-Spectral Scanner; Mexico

\section{INTRODUCTION}

Mangroves are a group of highly adapted halophytes occupying the intertidal zone in estuaries, lagoons, and coastal mud flats in tropical and subtropical areas. The presence of fresh water, at least temporarily, is needed for their survival (Blasco 1984, Tomlinson 1986, Gang and Agatsiva 1992, Tack and Polk 1999). Mangroves fulfil a prominent role in fueling the trophic web by producing leaf litter and detrital matter (Day et al. 1987). However, the estuary-feeding function of mangroves is not universal (Bouillon and Dehairs 2000, Bouillon et al. 2000), and evidence for inwelling rather than outwelling has been proposed for some systems (Bouillon et al. 2003). Nevertheless, mangroves have been found to enhance and sustain the natural biomass of coral reef fish (Mumby et al. 2004) as well as artificially raised aquaculture products
(Naylor et al. 2000a,b). Furthermore, mangrove forests enhance water quality by trapping nutrients and heavy metals (Alongi 1996, Clark 1998, de Lacerda 1998, Tam and Wong 1999).

Mangroves are socioeconomically important ecosystems, especially for the inhabitants of coastal regions, who depend on them as their primary source of income, fuel, food, medicine, and other basic necessities (Aksornkoae et al. 1993, Bandaranayake 1998, Dahdouh-Guebas et al. 2000a). Mangroves are also esthetically attractive for visitors. However, all over the world mangrove ecosystems are threatened with destruction through various forms of human pressure, in particular, extraction, pollution, and reclamation (Farnsworth and Ellison 1997). Moreover, the species richness of mangroves in many geographical areas is decreasing over time as a result of the destruction of mangrove forest and 
exposure to various anthropogenic impacts (Hamilton and Snedaker 1984), and the worldwide range of these forests is less than $50 \%$ of their original total cover (Saenger et al. 1983, Spalding et al. 1997). Recently, less obvious qualitative degradation has been reported in the form of transitions in species composition from preferred to less preferred and from true or vulnerable mangrove species to more disturbance-resistant species and mangrove associates (Dahdouh-Guebas et al. 2000b, Jayatissa et al. 2002, Kairo et al. 2002, Dahdouh-Guebas et al. 2005a,b). Overexploitation by traditional and commercial users and replacement and degradation as a consequence of development for other uses are also major problems of mangrove environments (Kapetsky 1987, Gang and Agatsiva 1992, Pérez Osuna 2000).

Serious social consequences can result from the large-scale destruction of mangroves, because rural communities are extremely dependent on the resources they provide (Dahdouh-Guebas et al. 2000a, Martín 2000). These rural communities end up concentrating their collection efforts in increasingly small areas, ultimately causing a higher impact in terms of overuse (Martín 2000), but overexploitation can also mean that people have to travel further to collect mangrove products (Flaherty and Karnjanakesorn 1995). Construction materials, charcoal, firewood, and traditional medicinal plants are all considered to be essential resources that are ultimately provided by the mangrove (Bailey 1988, Flaherty and Karnjanakesorn 1995, Kovacs 1999).

Like most developing countries, Mexico has a growing population; as a result, the increasing use of its resources is endangering several ecosystems. This is particularly true for the coastal lagoons where mangrove forests grow. Mangroves are being lost in Mexico mainly because coastal areas are being cleared for agriculture, mariculture, and urban development (Spalding et al. 1997, Alonso Pérez et al. 2003, Ruiz Luna and Berlanga Robles 2003). Saenger et al. (1983) reported that mangroves in Mexico have been used as a source of firewood, charcoal, tannins, medicines, fish, pasture, and construction materials. Flores Verdugo (1989) described similar findings, adding that mangroves are also used as hanging bars for the tobacco leaves in the drying galleries.

With this in mind, the aims of this study were (1) to use remote sensing to evaluate changes in the mangrove vegetation cover on the Navachiste-San Ignacio-Macapule lagoon complex from 1973 to 2000 and (2) to provide current data on traditional mangrove forest uses by local communities, including their perceptions of spatiotemporal changes.

\section{STUDY AREA}

The Navachiste-San Ignacio-Macapule is a complex of coastal lagoons located in the northern part of the Mexican State of Sinaloa, in the municipalities of Guasave and Ahome (Fig. 1). Geographically, it is situated between $25^{\circ} 17^{\prime}$ and $25^{\circ} 40^{\prime}$ North latitude, and between $108^{\circ} 25^{\prime}$ and $109^{\circ} 02^{\prime}$ 'West longitude. It extends about $45 \mathrm{~km}$ along the coast, with a total surface of approximately 27,000 ha for all the lagoons together (Berlanga Robles and Ruiz Luna 2002). This lagoon complex has a permanent connection with the Gulf of California through two mouths that create a marine environment most of the year. The surrounding terrestrial vegetation in the nothern part of this system is scarce and, because of the rocky terrain and limited rainfall, most of it consists of the shrubs and trees typical of a tropical dry forest and desertlike columnar cacti. Mangrove communities also occur in this area, which covers about $7 \%$ of the total surface of the municipality of Guasave. The dominant species is Rhizophora mangle L., followed by Avicennia germinans (L.) Stearn, Laguncularia racemosa (L.) Gaertn f., and the mangrove associate Conocarpus erectus L. The climate of the study area is categorized as temperatesubhumid with summer rains (INEGI 2000).

At present, the main activity in the study area, including almost $70 \%$ of the Guasave municipality, is intensive agriculture characterized by the use of irrigation and of high levels of fertilizers and pesticides whose aim is to greatly increase yield and productivity. Another important activity is fishing, with most of the catch being harvested by artisanal fishermen. In addition, there is a well-developed industrial shrimp fishery; shrimp aquaculture has become so important over the last two decades that it now conflicts with other activities such as traditional fisheries and agriculture (Ruiz Luna and de la Lanza Espino 1999).

The main sources of contamination for the Navachiste-San Ignacio-Macapule lagoon complex 
Fig. 1. Study area and location of the four fishery villages.

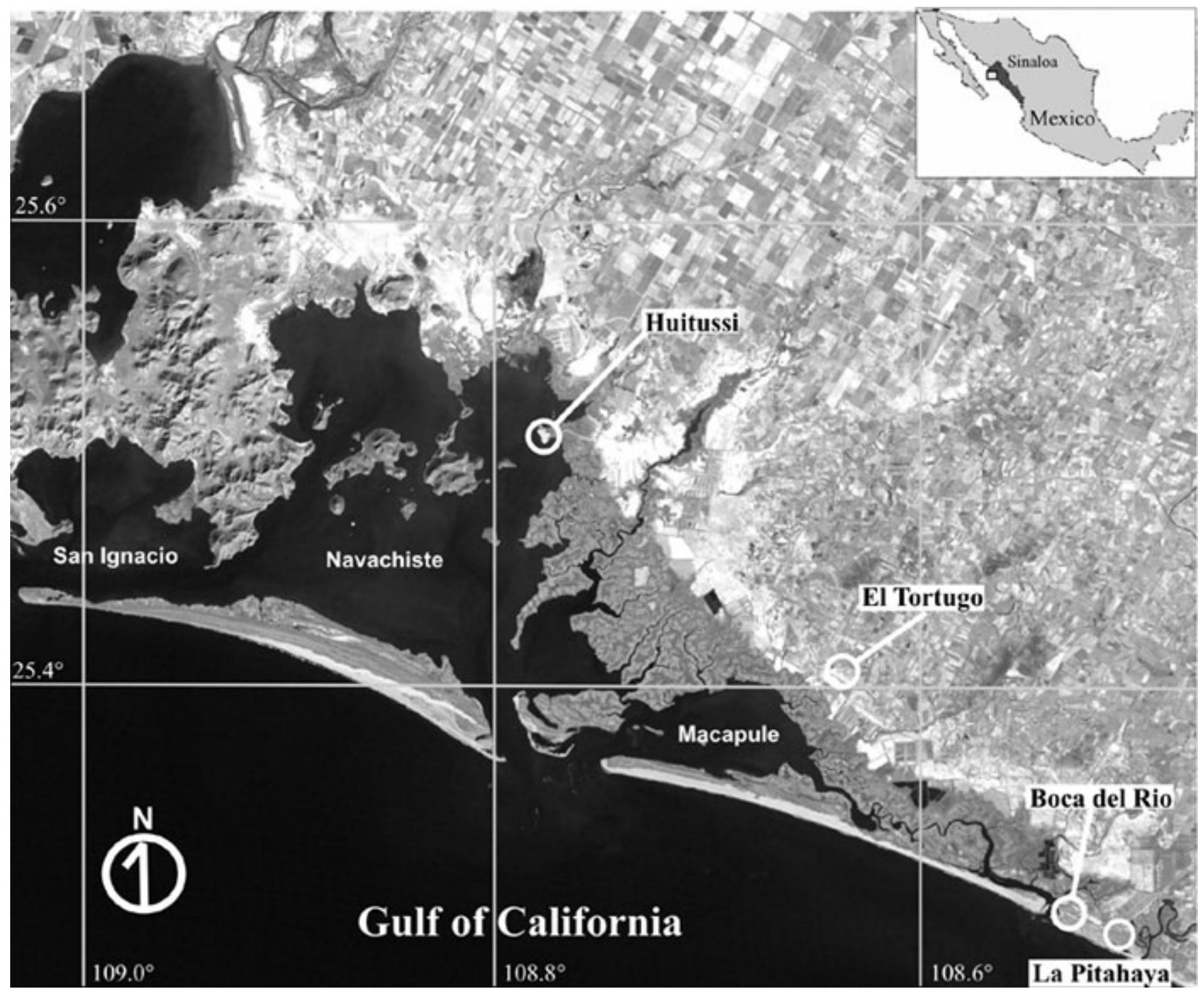

are municipal sewage from the main town in the area, Guasave (300,000 inhabitants); agricultural drainage, which transports fertilizers and biocides; and drainage from the shrimp farms, which includes organic nutrients, especially during the harvest, that flow into this system (Ruiz Luna and de la Lanza Espino 1999).

The lack of data on the status of the mangrove in this area has made it difficult to appraise the community; most of the available knowledge comes from the local people, who have strong ties with this ecosystem because of the economic activities they practice there. Furthermore, the presence of the growing shrimp farm industry may involve changes in land use and hydrologic dynamics that could render the mangrove community vulnerable to modifications to its cover. 


\section{METHODS}

\section{Survey of villagers' knowledge of local mangroves}

In July 2001, we visited four fishing grounds in the study area near the villages of La Pitahaya, Boca del Río, El Tortugo, and El Huitissi (Fig. 1). The populations of these coastal villages, whose only services are electricity and a limited supply of potable water, range from 36 inhabitants in La Pitahaya to more than 2700 in El Huitussi. We interviewed fishermen who were long-term residents to determine the uses made of mangrove by the local people; all those interviewed were male, ranging in age from 30 to $70 \mathrm{yr}$, because of a local gender bias in the division of labor. The subjects were chosen at random from all parts of the villages, with the exception of La Pitahaya, where representatives from most households were interviewed. Only one person per household was interviewed to avoid repetition of information. The interviews were conducted in Spanish, because this is the official language of Mexico, and later translated into English during the analysis. The objective of the questionnaires was to obtain information about local uses of mangrove trees, economic dependence or use relationships, the evolution of the forest, and issues related to conservation and protection of the mangrove forest (Appendix I).

An important aspect of the interviews was to determine how much the local villagers knew about the mangroves, in particular their use of the different parts of the tree, their preferences for particular species, and their observations of mangrove forest changes over time. The level of knowledge was defined as "very good" when most of the questions on mangrove identification were answered correctly and the respondent demonstrated familiarity with mangrove uses, had general information on the extension and characteristics of the mangrove areas, and knew about protection and conservation strategies. The level of knowledge was "good" when the respondent knew about only one or two of the general issues included in the questionnaire, and "fair" when the respondent was unable to answer most of the questions fully or correctly.

To get a better understanding of mangrove usage over several decades, only older men were selected and grouped in the age classes 30-40, 40-50, 5060, and 60-70 yr. Chi-square and $G$ tests were applied to analyze the different responses from each village, and the results were combined to obtain an approximation for the whole study area.

\section{Survey of mangrove forest}

Two surveys on the mangrove forest were carried out in the study area during July 2001 to obtain 12 ground control points (GCPs) for georeferencing, along with sampling points that were used to assess the accuracy of the supervised classifications. The land surveys were made during short trips into the mangrove forest, whereas the estuaries were surveyed using a boat $5 \mathrm{~m}$ long borrowed from the local fishermen. A total of 155 sampling points were recorded with a GPS model Trimble Navigations Ensign $\mathrm{xl}$ to record the co-ordinates at each sampling point.

\section{Remote sensing techniques}

The analysis is based on a multitemporal satellite imagery study that included the Navachiste-San Ignacio-Macapule lagoon complex and the adjacent area covered by mangrove forest, the extent of which was analyzed over time. As a result of the analysis, thematic maps with supervised classifications were prepared to obtain a land-cover map. In total, four Landsat satellite images were analyzed corresponding to the path/row 33/42 (35/42,43 under WRS-1). Three of them were taken with the Multispectral Scanner (MSS) and corresponded to 24 March 1973, 24 March 1986, and 3 May 1992. One image was taken with the Enhanced Thematic Mapper (ETM+) on 22 May 2000. The three Landsat MSS images were donated by the North American Landscape Characterisation (NALC) project of the U.S. Geological Survey, and the TM image was a donation from Mexico's secretariat for the environment, natural resources, and fisheries (SEMARNAP). All the images were recorded in approximately the same season between March and May, which corresponds to the dry season in the region. The satellite imagery set was processed using version 2.7 of Multispec for Windows from the Purdue Research Foundation (West Lafayette, Indiana, USA) and version 32.22 of Idrisi32 from Clark Laboratories (Jamestown, New York, USA). Two land-use and vegetation maps, as well as aerial photography from 1995 obtained from Mexico's national institute of geographical statistics and information (INEGI), were used as ancillary data to 
complement the results of the classifications.

To determine the accuracy of the thematic map obtained using the supervised classification from 2000 as the latest image, an accuracy assessment was carried out using the GCPs recorded during the field survey. Overall accuracy was calculated, based on an error matrix that included mangrove, nonmangrove, and water classes, as the percentage of agreement between GCP reference points and the classification results (Congalton and Green 1999).

By means of a postclassification method, the ETM+ image was geometrically corrected in relation to the MSS images to obtain the same spatial resolution, i.e., from $30 \mathrm{~m}$ to $60 \mathrm{~m}$. The classified scenes in the time data set were compared on a pixel-by-pixel basis to separate the mangrove and nonmangrove classes, and a matrix was obtained showing the proportion of pixels that changed in the mangrove forest class. The pixels were transformed into area by date and compared using a cross-classification by pairs of scenes. This procedure compares the pixels for all the classes in one image with those of a second image, noting the proportion of change and the measures of agreement between the images or dates, and then outputs a new image that displays the changes.

\section{RESULTS}

\section{Villagers' knowledge level}

In total, 54 interviews were completed, representing $1.5 \%$ of the total population of La Pitahaya, Boca del Río, El Tortugo, and El Huitussi. The results showed that all the age groups included in the sampling were well represented: $29.7 \%$ belonged to the $60-70$ age class; $22 \%$, to the 50-60 age class; $27.8 \%$, to the $40-50$ age class; and $20 \%$, to the $30-$ 40 age class.

The analysis of the questionnaires for the combined data from the Navachiste-San Ignacio-Macapule lagoon complex indicated very clearly that most of those interviewed $(72 \%)$ had a very good knowledge of the mangrove forest. Of those remaining, 22\% had a good knowledge, and only $6 \%$ of the respondents were ranked below that, indicating that the results are trustworthy and provide a good basis for mangrove evaluation. Combining age with knowledge by means of a $G$ test, no significant difference was found between the age classes and the knowledge of the villagers $(G=29.6$, d.f. $=6 ; p>0.1)$.

\section{Mangrove species and use patterns}

The results of the survey showed that the four mangrove species that occur in the Navachiste-San Ignacio-Macapule lagoon complex are known by a variety of local names. For example, Rhizophora mangle was called chirigote; Avicennia germinans went by cenizo or prieto; Laguncularia racemosa was referred to as rojo, colorado, or canaral; and Conocarpus erectus was known as botoncillo.

Distribution patterns of mangrove trees were heterogeneous, with some areas bordering the lagoons and estuaries dominated by a single species (R. mangle, A. germinans, or L. racemosa), whereas in other areas these three species were mixed. Most respondents recognized $L$. racemosaand $R$. mangle as the two most abundant species in the study area.

Although each species has common uses (Table 1), there were some differences in usage patterns when data from individual villages were analyzed. Most of the respondents from El Huitussi, Boca del Río, and La Pitahaya used mangrove for firewood, compared with only $20 \%$ of the interviewees from El Tortugo (Fig. 2). Nobody from El Tortugo intensively used mangrove for construction, although it did provide medicine and a soft drink. People from La Pitahaya, the smallest village, made the most intensive use of mangrove, with up to $100 \%$ of positive responses for firewood and other uses. More than $80 \%$ of the respondents from La Pitahaya used mangrove as medicine compared with the other villages, in which mangrove was used for this purpose by fewer than $50 \%$ of the interviewees (Fig. 2 ). It is important to mention the use of medicinal tea made from the leaves of Avicennia germinans, especially for the treatment of gastric diseases. With regard to intensity of mangrove use, the four villages are ranked in decreasing order: La Pitahaya, El Huitussi, Boca del Río, and El Tortugo. The results of a $G$ test showed no significant differences among the four villages in terms of the villagers' knowledge of the uses of mangrove $(G=3.4$, d.f. $=8 ; p>0.1)$.

By species, L. racemosa was cited most often by the interviewees, representing almost $50 \%$ of the total responses, but clear differences were observed when analyzing the individual villages. L. racemosa 
Table 1. Traditional uses of mangrove by local people from the Navachiste-San Ignacio-Macapule lagoon complex.

\begin{tabular}{lll}
\hline \hline Species name & Local names & Uses \\
\hline $\begin{array}{l}\text { Laguncularia racemosa } \\
\text { Rhizophora mangle }\end{array}$ & $\begin{array}{l}\text { mangle rojo, colorado or } \\
\text { manaral }\end{array}$ & $\begin{array}{l}\text { Firewood (home use); construction: roof terraces, } \\
\text { ceilings, walls, fences; row poles; fishing traps }\end{array}$ \\
Avicennia germinans & mangle cenizo or prieto & $\begin{array}{l}\text { Firewood (home use); construction: roof terraces, } \\
\text { ceilings, walls, fences; medicine, tea }\end{array}$ \\
Conocarpus erectus & mangle botoncillo & Firewood (home use) \\
\hline
\end{tabular}

was used by $41 \%, 57 \%$, and $66.7 \%$ of the respondents in Boca del Río, El Huitussi, and La Pitahaya, respectively. In contrast, in El Tortugo only $10 \%$ of the respondents said that they used this species, and, moreover, the survey results indicated that $90 \%$ of the responses did not specify any particular use for mangroves. Only the respondents from El Huitussi made relatively high use (12\%) of a second species (Avicennia germinans), and a mere $8 \%$ of them used a third species. Overall results showed that the inhabitants of El Huitussi $(77 \%)$ and La Pitahaya (83.4\%) used more mangrove resources than did the people from the other two villages. Knowledge of mangrove species and uses was especially remarkable among those aged 60$70 \mathrm{yr}$; in addition to being able to identify mangrove species, this group provided information on specific uses. The principal species used was L. racemosa, mainly in the villages of Boca del Río, El Huitussi, and La Pitahaya, for the construction of roof terraces, ceilings, walls, and fences. Some interviewees explained that this species was normally treated by burying the logs in soil for 20$30 \mathrm{~d}$ to cure the wood, which increased its endurance by up to $6-8 \mathrm{yr}$.

With regard to the villagers' perceptions about the past and current extent of the mangrove cover, there was a general notion that it had been reduced $(63 \%$ of the total responses). In contrast, only $5 \%$ noticed an increase in the area covered by mangrove. Alhough El Tortugo villagers did not use mangrove trees intensively, they were aware of changes in mangrove cover. Eighty percent, $77 \%$, and $67 \%$ of the respondents from El Tortugo, El Huitussi, and La Pitahaya, respectively, were of the opinion that the mangrove cover had decreased. Only $17 \%$ of those interviewed in Boca del Rí0 noted a decrease in mangrove cover, whereas $66 \%$ responded that there had been no significant changes; a small proportion from El Huitussi $(11.5 \%)$ claimed an increase in mangrove cover.

Similar results were recorded for respondents' views on the future of the mangrove cover. Most of those interviewed $(61 \%)$ believed that there would be a decrease in mangrove cover; $59 \%$ associated this loss with the construction of shrimp farms and $39 \%$, with natural events such as hurricanes and tropical storms. In particular, $75 \%$ and $67 \%$ of the inhabitants of La Pitahaya and Boca del Río, respectively, blamed natural events without specifying their nature, whereas foreign consumption by illegal cutters and clearing for house construction were considered to be the least destructive causes of mangrove loss. Despite these findings, $58 \%$ of the respondents from Boca del Río did not expect changes in mangrove extension in the near future.

Coincidentally, La Pitahaya and Boca del Río are located in the southern part of the study area, close to one another and more exposed to natural events coming from the sea. In contrast, El Tortugo and El Huitussi are closer to shrimp farms, and $61 \%$ and $60 \%$ of the respondents from these villages, respectively, associated mangrove loss with this economic activity. Villagers from El Huitussi also included foreign consumption of mangrove for firewood and house construction as causes of mangrove decline.

Testing the relationship between the causes of 
Fig. 2. Different uses of mangrove by local villagers from La Pitahaya, Boca del Río, El Tortugo, and El Huitussi villages (Sinaloa, Mexico).

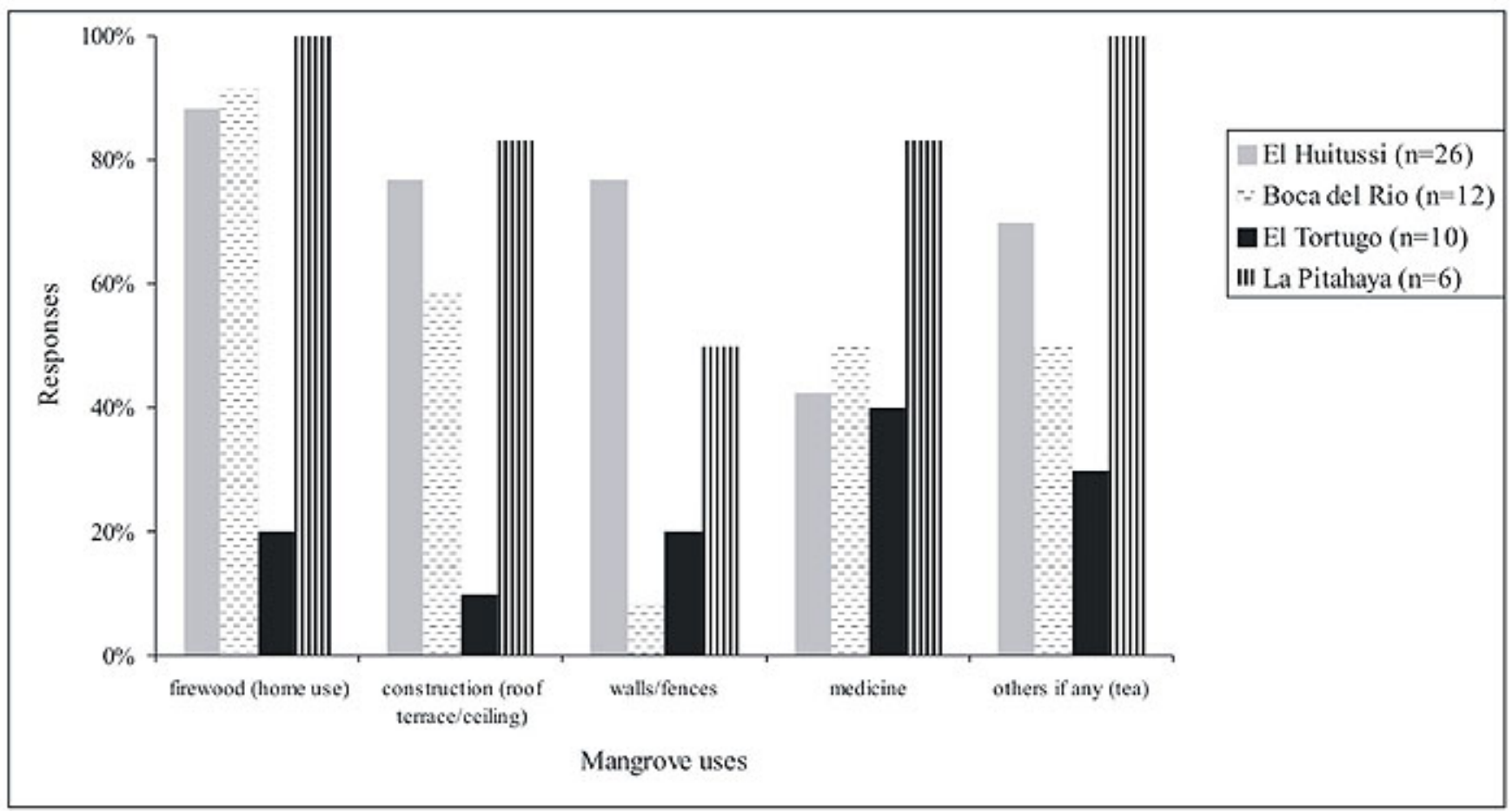

mangrove depletion and the knowledge of the villagers showed that there was no significant relationship between these variables $(G=0.78, \mathrm{~d}$. f. $=3 ; p>0.1)$.

\section{Mapping mangrove forest with Landsat MSS and ETM imagery}

The error matrix for the 2000 Landsat image classification was carried out using the 155 ground control points (GCPs) identified during the mangrove surveys, and the overall agreement between the GCPs and the supervised classification results was $85 \%$. The few cases of confusion occurred between mangrove and nonmangrove points. This level of accuracy for the classification was accepted, and the output map was considered a suitable representation of the landscape characteristics of the area. Despite the fact that no field data were available for the previous images, we assumed a similar accuracy level for the other outputs because we used the same classification procedure.

Supervised classifications were compared to analyze changes in the mangrove cover from 1973 to 2000; the results indicated an average value of about 11,050 ha, with a maximum of 11,490 ha in 1992 and a minimum of 10,580 ha in 1986 (Table 2). Calculations made by comparing the images from $1973,1986,1992$, and 2000 on a pixel-by-pixel basis and transforming the findings into hectares, plus the total balance by date (Table 2), indicated that the pixels classified as mangrove cover maintained a constant cover of about 8500 ha throughout the 27-yr period (Fig. 3). Changes in the spatial distribution of pixels classified as mangrove resulted in positive and negative variations between dates, with interperiod loss or gain, but with an overall gain of around 540 ha or $5 \%$ of the total area assessed for 1973 . 
Table 2. Matrix representing a pixel-by-pixel comparison between the areas (ha) of mangrove forest from 1973, 1986, 1992, and 2000 (figures are rounded to the nearest 10).

\begin{tabular}{llrrr}
\hline \hline & \multicolumn{1}{l}{$\mathbf{1 9 7 3}$} & $\mathbf{1 9 8 6}$ & $\mathbf{1 9 9 2}$ & $\mathbf{2 0 0 0}$ \\
\hline Estimated mangrove area & 10790 & 10580 & 11490 & 11330 \\
Remaining area of 1973 mangrove & $\ldots$ & 8490 & 8430 & 8860 \\
Increase in mangrove compared with 1973 & $\ldots$ & 2100 & 3070 & 3150 \\
Mangrove loss compared with 1973 & $\ldots$ & 2310 & 2360 & 2610 \\
Net change compared with 1973 & $\ldots$ & -210 & +700 & +540 \\
\hline
\end{tabular}

\section{DISCUSSION}

\section{Villagers' knowledge level}

Present results on villagers' perception of mangroves in the Navachiste-San IgnacioMacapule lagoon complex are considered trustworthy, because most of the interviewees had very good to good knowledge, as identified by their ability to name and differentiate between the mangrove species in the region. Although the number of interviewees was relatively low, it represented about $1.5 \%$ of the total population for the four villages; the fact that only a single male from each household was interviewed must also be taken into consideration.

The results indicated that some knowledge patterns were quite similar for the villages of La Pitahaya, Boca del Río, and El Tortugo, whose inhabitants displayed very good and good knowledge about mangroves, but there were noticeable differences with El Huitussi, which also included respondents with only a fair knowledge of local mangroves. However, statistical tests do not indicate any significant differences. It should be noted that, as the largest village in the study area, El Huitussi has more diversity in job types than the others, so that its inhabitants are not as dependent on mangroves as the other villagers. Similar results were found by Kovacs (1999) in the Teacapan-Agua Brava system located in the southern limits of Sinaloa State, where villagers at once distinguished the four species present in that area, although there were at least two variants of the most common species (Languncularia racemosa).
From all the mangrove uses reported (Kovacs 1999, Dahdouh-Guebas et al. 2000a, Kajia 2000, Obade 2000, Stolk 2000), firewood, construction of roof terraces and ceilings, and tea represented the most frequently reported by the villagers in the study area. Mangroves were also used to build walls and fences and for tanning and medicinal purposes, but not with the same intensity. Results from Kovacs (1999) were similar for the Teacapán-Agua Brava estuarine system, which is only about $200 \mathrm{~km}$ away from the study area. There is not much difference in the potential uses of mangrove in both study areas, which indicates that Mexicans in this region use the mangroves for similar purposes.

Similar uses for mangrove have been recorded in Africa (Dahdouh-Guebas et al. 2000a, Kajia, 2000 and Obade 2000), and Asia (Stolk 2000), with levels from $92 \%$ to $100 \%$ for firewood and building materials, and equally high levels for therapeutic products. Interestingly, in the study area, inhabitants from El Tortugo made relatively limited use of the mangrove resources, despite the proximity of this village to a dense mangrove area. This could be related to the main economic activity of the villagers, which is concentrated on local shrimp farms.

Medicinal use in the study area was high for all four villages and averaged $45 \%-50 \%$ of respondents, who used mangrove to lose weight and to alleviate problems associated with gastritis, ulcers, blood circulation, and blotchy skin. Similar responses in other areas were obtained by Kovacs (1999), Kajia (2000), Dahdouh-Guebas et al. (2000a), and Obade (2000); of these references, only Dahdouh-Guebas et al. (2000a) provide details of the individual 
Fig. 3. Thematic map for the Navachiste-San Ignacio-Macapule lagoon complex, representing the mangrove cover changes from 1973 to 2000.

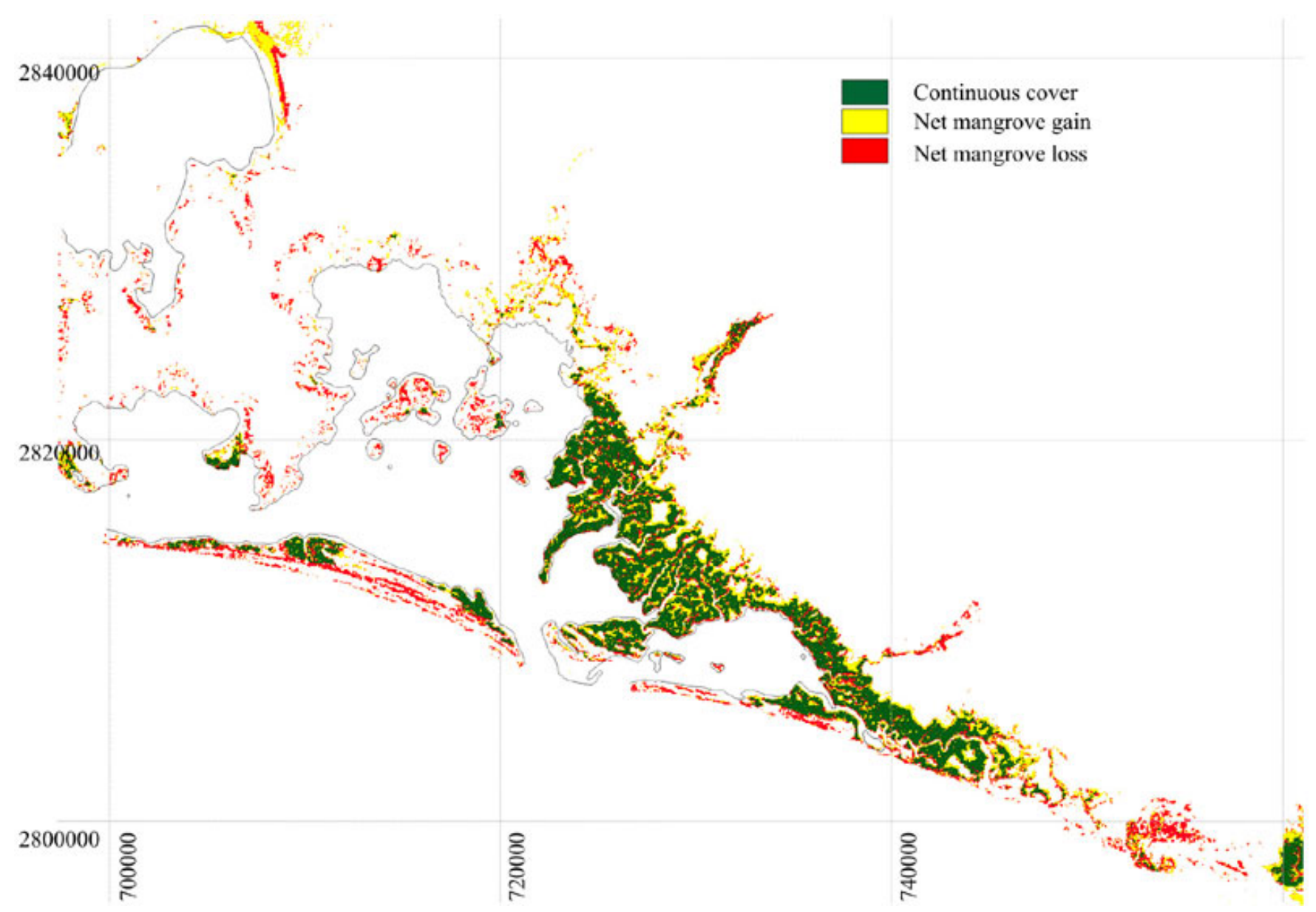

medicinal uses. Interestingly, the use of species other than mangrove to cure skin disorders was also noted by Dahdouh-Guebas et al. $(2000 a)$, who listed additional medicinal uses that were not found in the present study, e.g., in ointments and to relieve constipation, fertility-related or menstrual disorders, and aching muscles and limbs. Kovacs (1999) reported the use of mangrove tea to alleviate some diseases, but he also mentioned that Laguncularia bark tea was not able to cure skin diseases. Other uses found worldwide, such as charcoal processing (Aksornkoae et al. 1993), are not reported here.

Results from the interviews showed that $L$. racemosa is the most frequently used species in this region for domestic firewood and the construction of roof terraces, ceilings, walls, and fences. Avicennia germinans (mangle cenizo or prieto) is used mainly for tea, Rhizophora mangle (mangle chirigote) is used mainly for tanning, and both are used for medicine. A variety of local names for mangrove was noted, e.g., the local name for $L$. racemosa was rojo, which in Mexico is commonly used to refer to $R$. mangle.

The older age groups were able to provide more information on mangrove uses, particularly how to process the wood and prepare medicines. They informed us that mangrove wood from L. racemosa, when used for building, lasts about $7 \mathrm{yr}$. However, this species is not present in the old world where others studies have been done, such as Dahdouh- 
Guebas et al. (2000a), who reported that mangrove wood can last up to $30 \mathrm{yr}$ when used for house construction in Kenya. Other authors (Kovacs 1999, Dahdouh-Guebas et al. 2000a, Kajia, 2000) also noted the use of specific mangrove species for the construction of items such as fishing poles, walls, and fences, but do not mention any specific technique for enhancing the properties of the wood. Obade (2000) recognized that mangroves were used for firewood and building, but did not report the particular species used for these purposes. The findings of this study help update our knowledge of the status of mangrove in Mexico, and we agree with Kovacs (1999), who mentioned that current beliefs about mangrove forest use in coastal areas of the country is out of date and inadequate because it does not take into account how widely used this resource is. Although present findings on the mangrove area are very important, new studies are currently being carried out by the authors in northwest Mexico, including the present study area, to obtain details on mangrove species distribution and forest structure as potential tools for the management of this resource, as illustrated by Dahdouh-Guebas (2002) and Dahdouh-Guebas and Koedam (2002).

\section{Mapping mangrove forest with Landsat MSS and ETM imagery}

In the present study, three of the four Multispectral Scanner images used had rather limited spectral signature discrimination, meaning that, in the spectral resolution of these images, only four spectral bands were available, compared to the seven bands present in Ehanced Thematic Mapping images. However, results from the classifications were very consistent between dates, and the output of the supervised classification for the year 2000 gave accuracy levels high enough to assume a reliable characterization of the mangrove cover in the area (85\%). This accuracy level implies an error inherent in the classification process that was minimized but not eliminated. A similar error can be supposed for the rest of the map outputs, given that the imagery processing is the same (Berlanga Robles and Ruiz Luna 2002).

According to these results, the mangrove vegetation cover in the Navachiste-San Ignacio-Macapule lagoon complex has increased marginally over the last $27 \mathrm{yr}$, but the rate of spatial increase (about 20 ha/yr) is not always a good indicator of a positive trend. In fact, spatial increases in mangrove areas have been found to mask qualitative degradation at different sites (Jayatissa et al. 2002, Kairo et al. 2002). Although variations in the extension of mangrove could in part be a result of between-date tidal differences, as was detected along the coastline, especially in the area of the bay mouth bars, the changes are not large enough to consider this as the main source of error in the classification. In addition, there were interperiod variations (19731986, 1986-1992, 1992-2000), both positive and negative, that are related mainly to the dynamics of the mangrove vegetation structure (sensu DahdouhGuebas and Koedam 2002). From 1973 to 1986, the mangrove vegetation cover had a negative balance; it lost more than 200 ha, which were recovered during the next period (1986-1992), giving a total balance of 700 ha from 1973 to 1992 . In the last period (1992-2000) there was another loss, but over the entire $27-y r$ period the net change was positive. In any case, it was not possible to analyze the change in species composition, and our results take into account only the mangrove/nonmangrove covers.

Until now, it seems that this is one of the few studies of the entire coastline of the State of Sinaloa that reports an increase in the mangrove cover. Comparing these findings with those of other authors studying the region, it would seem that the coverage of natural vegetation, both mangrove and dry forest, decreased by about 14,000 ha in the Huizache-Caimanero lagoon system between 1973 and 1997 (Ruiz Luna and Berlanga Robles 1999). These authors also pointed out that, at present, mangrove swamps are found only in small patches next to rivers, and reported a loss of about $15 \%$ of the mangrove coverage over a $24-\mathrm{yr}$ period in the Estero de Urías-El Infiernillo system, also situated in the southern part of the State of Sinaloa. This change was attributed to the expansion of urban zones and agricultural areas, with the development of shrimp farming having only a marginal effect.

Berlanga Robles and Ruiz Luna (2002) and Alonso Pérez et al. (2003) reported that the mangrove cover in two areas of Sinaloa had remained almost constant, with only a slight loss of this cover over periods of 24 and $15 \mathrm{yr}$, respectively. Remarkably, the former authors also found a considerable increase in the extension of the mangrove area during 1986, which is in line with the results reported here.

It is clear that the mangrove vegetation cover can display great variability depending on its dynamics, 
environmental events, and developing activities in the area. This could be the case with the NavachisteSan Ignacio-Macapule lagoon complex, where the local villagers do not really exploit the mangrove resource as a commercial activity and where shrimp farming seems not to have had a significant negative effect on mangrove extension. This may be the cause of the permanent increase in the mangrove vegetation cover over the last $27 \mathrm{yr}$, with variations probably due to the natural dynamics of this ecosystem, although there is currently no information on the study area to support this.

Also, natural variations in mangrove coverage could be a product of the perceptions of the local villagers, who believed that the local mangrove had begun and was continuing to decline. Different mangrove areas studied all over the world show different responses as to whether the mangrove cover had increased or decreased. Obade (2000) recorded that $69 \%$ of the villagers from Gazi Bay, Kenya, were of the opinion that the local mangrove forest had increased in cover. However, based on remote sensing and interviews, Dahdouh-Guebas et al. (2004) reported that the mangrove cover has decreased in at least the most accessible area of Gazi Bay.

Present findings reveal a possible discrepancy between these two analyses, or simply two different types of information. Remotely sensed data showed that there had been an increase in mangrove vegetation cover, whereas the local villagers had the opposite perception. This could be because the perception of the villagers was based on the intensity of use, e.g., depending on the locality, the mangrove species were used more intensively for fencing and construction. Although in a landscape vision losses are not significant, spatially it was evident that mangrove losses had occurred in three out of the four villages investigated. It should also be emphasized that survey answers might reflect information about density or basal area, which describe the forest floor, whereas our remotely sensed imagery reflects the reality of the forest canopy. These two types of information are not always in line (cf. Dahdouh-Guebas et al. 2005b). Another possible explanation for the discrepancy may be the stronger perception of loss of function by local people. In India, for example, the loss of the anti-erosion function of seaward mangroves is more obvious to the inhabitants of nearby villages that are subjected to more frequent flooding hazards (Collin 2002). At our study site, this may also be the case for people who are more familiar with the bay islands and land stretches on which the mangrove loss occurred (Fig. 3). Our results thus indicate either that there is a difference between what people perceive and what is actually being recorded by current remote sensing technology, or that these two sources of information refer to different processes, such as quantitative increase vs. qualitative, e.g., ethnobotanical, silvimetrical, functional, degradation. It is also probable that the perception of the interviewees did not take into account the natural displacement of the mangrove cover associated with its own evolution and dynamics in the area.

For this reason, the present study stresses the importance of combining both questionnaires and satellite imagery analysis. A better spatial resolution may be able to evaluate fully the situation in the area to be studied; this is corroborated by the fact that very high resolution may even reveal introgressive specimens (Dahdouh-Guebas et al. 2004), which local people may experience as negative. It is also proposed that a new survey be conducted so that those interviewed can identify locations in which mangrove decrease is reported to have taken place. These locations can subsequently be analyzed by remote sensing to determine whether the decrease identified by the survey respondents can be clearly visualized using this technique. The findings from such a study might also provide insights into any differences of scale between the views of the respondents and the scope of remote sensing. Furthermore, targeted ground-truthing in areas in which mangrove is said to have increased or decreased must be carried out; traces of previous land cover or land use might help to assess the trustworthiness of remote sensing in our type of application.

Responses to this article can be read online at: http://www.ecologyandsociety.org/vollo/iss 1/art16/responses/

\section{Acknowledgments:}

Farid Dahdouh-Guebas is a postdoctoral researcher from the Fund for Scientific Research (FWO-Vlaanderen). The research was also funded by the Flemish Interuniversity Council (VLIR) as a student grant to Rubi Hernández Cornejo. We acknowledge C. A. Berlanga Robles and J. Acosta 
from the Environmental Management Laboratory (CIAD), as well as F. Flores Verdugo from the Marine and Limnology Sciences Institute (UNAM) for their help in this study. This research is within the objectives of the Interational GeosphereBiosphere Programme (IGBP), Past Global Changes (PAGES) Focus 5: Past Ecosystem Processes and Human-Environment Interactions.

\section{LITERATURE CITED}

Aksornkoae, S., N. Paphavasit, and G. Wattayakorn. 1993. Mangroves of Thailand: present status of conservation, use and management. Pages 83-132 in International Tropical Timber Organisation, Japan International Association for Mangroves, and International Society for Mangrove Ecosystems. The economic and environment value of mangrove forests and their present state of conservation. International Society for Mangrove Ecosystems, Okinawa, Japan.

Alongi, D. M. 1996. The dynamics of benthic nutrient pools and fluxes in tropical mangrove forests. Journal of Marine Research 54:123-148.

Alonso Pérez, F., A. Ruiz Luna, J. Turner, C. A. Berlanga Robles, and G. Mitchelson Jacob. 2003. Land cover changes and impact of shrimp aquaculture on the landscape in the Ceuta coastal lagoon system, Sinaloa, México. Ocean and Coastal Management 46:583-600.

Bailey, C. 1988. The social consequences of tropical shrimp mariculture development. Ocean \& Shoreline Management 11:31-44.

Bandaranayake, W. M. 1998. Traditional and medicinal uses of mangroves. Mangroves and Salt Marshes 2:133-148.

Berlanga Robles, C. A. 1999. Evaluación de las condiciones actuales y del cambio en los paisajes de humedales de la costa sur de Sinaloa, México: una aproximación con el uso de datos provenientes de sensores remotos. Thesis, Universidad Autónoma de México, Mexico City, Mexico.

Berlanga Robles, C. A., and A. Ruiz Luna. 2002. Land use mapping and change detection in the coastal zone of northwest Mexico using remote sensing techniques. Journal of Coastal Research 18:514-522.

Blasco, F. 1984. Climatic factors and the biology of mangrove plants. Pages 18-35 in S. C. Snedaker and J. G. Snedaker, editors. The mangrove ecosystem: research methods. UNESCO, Paris, France.

Bouillon, S., and F. Dehairs. 2000. Estimating spatial and seasonal phytoplankton $\delta^{13} \mathrm{C}$ variations in an estuarine mangrove ecosystem. Isotopes in Environmental and Health Studies 36:273-284.

Bouillon, S., P. Chandra Mohan, N. Sreenivas, and F. Dehairs. 2000. Sources of suspended matter and selective feeding by zooplankton in an estuarine mangrove ecosystem, as traced by stable isotopes. Marine Ecology Progress Series 208:79-92.

Bouillon, S., F. Dahdouh-Guebas, A. V. V. S. Rao, N. Koedam, and F. Dehairs. 2003. Sources of organic carbon in mangrove sediments: variability and possible ecological implications. Hydrobiologia 495(1):33-39.

Clark, M. W. 1998. Management of metal transfer pathways from a refuse tip to mangrove sediments. Science of the Total Environment 222:17-34.

Collin, S. 2002. Ethnobotanical and fishery-related importance of mangroves of East Godavari Delta, Andhra Pradesh, India. Thesis, Vrije Universiteit Brussel, Brussels, Belgium.

Congalton, R. G., and K. Green. 1999. Assessing the accuracy of remotely sensed data: principles and practices. Lewis, New York, New York, USA.

Dahdouh-Guebas, F. 2002. The use of remote sensing and GIS in the sustainable management of tropical coastal ecosystems. Environment, Development and Sustainability 4(2):93-112.

Dahdouh-Guebas, F., C. Mathenge, J. G. Kairo, and N. Koedam. 2000a. Utilization of mangrove wood products around Mida Creek (Kenya) among subsistence and commercial users. Economic Botany 54(4):513-527.

Dahdouh-Guebas, F., A. Verheyden, W. De Genst, S. Hettiarachchi, and N. Koedam. 2000 b. Four decade vegetation dynamics in Sri Lankan mangroves as detected from sequential aerial 
photography: a case study in Galle. Bulletin of Marine Science 67:741-759.

Dahdouh-Guebas, F., and N. Koedam. 2002. A synthesis of existent and potential mangrove vegetation structure dynamics from Kenyan, Sri Lankan and Mauritanian case-studies. Bulletin des Séances de l'Académie Royale des Sciences d'OutreMer 48(4):487-511.

Dahdouh-Guebas, F., T. Zetterström, P. Rönnbäck, M. Troell, A. Wickramasinghe, and N. Koedam. 2002. Recent changes in land-use in the Pambala-Chilaw Lagoon complex (Sri Lanka) investigated using remote sensing and GIS : conservation of mangroves vs. development of shrimp farming. Environment, Development and Sustainability 4(2):185-200.

Dahdouh-Guebas, F., I. Van Pottelbergh, J. G. Kairo, S. Cannicci, and N. Koedam. 2004. Human-impacted mangroves in Gazi (Kenya): predicting future vegetation based on retrospective remote sensing, social surveys, and distribution of trees. Marine Ecology Progress Series 272:77-92.

Dadouh-Guebas, F., S. Hettiarachchi, D. Lo Seen, O. Batelaan, S. Sooriyarachchi, L. P. Jayatissa, and N. Koedam. 2005a. Transitions in ancient inland freshwater resource management in Sri Lanka affect biota and human populations in and around coastal lagoons. Current Biology 15 (6):579-586.

Dahdouh-Guebas, F., E. Van Hiel, J. C.-W. Chan, L.P. Jayatissa, and N. Koedam. 2005b. Qualitative distinction of congeneric and introgressive mangrove species in mixed patchy forest assemblages using high spatial resolution remotely sensed imagery (IKONOS). Systematics and Biodiversity 2(2):113-119.

Day, J. W., Jr., W. H. Conner, F. Ley-Lou, R. H. Day, and A. N. Machado. 1987. The productivity and composition of mangrove forests, Laguna de Terminos, Mexico. Aquatic Botany 27:267-284.

de Lacerda, L. D. 1998. Trace metals in mangrove plants: why such low concentrations? Page 171-178 in B. Kjerfve, L. D. de Lacerda, and E. H. S. Diop, editors. Mangrove ecosystem studies in Latin America and Africa. UNESCO, Paris, France.

Farnsworth, E. J., and A. M. Ellison. 1997. The global conservation status of mangroves. Ambio $\mathbf{2 6}$ (6):328-334.

Flaherty, M., and C. Karnjanekesorn. 1995. Marine shrimp aquaculture and natural resource degradation in Thailand. Environmental Management 19(1):27-37.

Flores Verdugo, F. J. 1989. Algunos aspectos sobre la ecología, uso e importancia de los ecosistemas de manglar. Pages 21-56 in J. de la Rosa Vélez and F. González Farias, editors. Temas de oceanograf\&\#0237a biológica en México. Universidad Autónoma de Baja California, Ensenada, Mexico.

Gang, P. O., and J. L. Agatsiva. 1992. The current status of mangroves along the Kenyan coast: a case study of Mida Creek mangroves based on remote sensing. Hydrobiologia 247:29-36.

Hamilton, L. S., and S. C. Snedaker. 1984. Handbook for mangrove area management. Commission on Ecology, IUCN, Gland, Switzerland.

Instituto Nacional de Estadística Geográfica e Informática (INEGI). 2000. Cuaderno estadístico municipal de Guasave, Sinaloa. Gobierno del Estado de Sinaloa, Culiacán Rosales, Mexico.

Jayatissa, L. P., M. C. Guero, S. Hettiarachchi, and N. Koedam. 2002. Changes in vegetation cover and socio-economic transitions in a coastal lagoon (Kalametiya, Sri Lanka), as observed by teledetection and ground truthing, can be attributed to an upstream irrigation scheme. Environment, Development and Sustainability 4(2):167-183.

Kairo, J. G., F. Dahdouh-Guebas, P. O. Gwada, C. Ochieng, and N. Koedam. 2002. Regeneration status of mangrove forests in Mida Creek, Kenya: a compromised or secured future? Ambio 31 (7/8):562-568.

Kajia, S. Y. 2000. Assessment of the effects of rice farming in the mangrove forest of the Rufiji delta (mainland Tanzania). Thesis, Vrije Universiteit Brussel. Brussels, Belgium.

Kapetsky, J. M. 1987. Conversion of mangroves for pond aquaculture: some short-term and longterm remedies. FAO Fisheries Report Supplement 370: 129-141.

Kovacs, M. J. 1999. Assessing mangrove use at the 
local scale. Landscape and Urban Planning 43:201-208.

Martín, A. A. C. 2000. Mangrove mapping and carrying capacity assessment of a tropical coastal lagoon in Mexico. Thesis, University of Wales, Bangor, UK.

Mumby, P. J., A. J. Edwards, J. E. Arlas González, K. C. Lindeman, P. G. Blackwell, A. Gall, M. I. Gorczynska, A. R. Harborne, C. L. Pescod, H. Renken, C. C. C. Wabnitz, and G. Llewellyn. 2004. Mangroves enhance the biomass of coral reef fish communities in the Caribbean. Nature 427:533-536.

Naylor, R. L., R. J. Goldburg, H. Mooney, M. Beveridge, J. Clay, C. Folke, N. Kautsky, J. Lubcheno, J. Primavera, and M. Williams. 2000a. Nature's subsidies to shrimp and salmon farming. Science 282:883-884.

Naylor, R. L., R. J. Goldburg, J. H. Primavera, N. Kautsky, M. C. M. Beveridge, J. Clay, C. Folke, J. Lubchenco, H. Moony, and M. Troell. $2000 b$. Effect of aquaculture on world fish supplies. Nature 405(29):1017-1024.

Obade, T. P. 2000. Anthropogenically induced changes in a Kenyan mangrove ecosystem explained by application of remote sensing and Geographic Information Systems (GIS). Thesis, Vrije Universiteit Brussel, Brussels, Belgium.

Obade, T. P., F. Dahdouh-Guebas, N. Koedam, R. De Wulf, and J. F. Tack. 2004. GIS-based integration of interdisciplinary ecological data to detect land-cover changes in creek mangroves at Gazi Bay, Kenya. Western Indian Ocean Journal of Marine Science 3(1):11-27.

Pérez Osuna, F. 2000. The environmental impact of shrimp aquaculture: a global perspective. Environmental Pollution 112:1-3.

Ruiz Luna, A., and C. A. Berlanga Robles. 1999. Modifications in coverage patterns and land use around the Huizache-Caimanero lagoon system, Sinaloa, Mexico: a multi-temporal analysis using Landsat images. Estuarine, Coastal and Shelf Science 49:37-44.

Ruiz Luna, A., and C. A. Berlanga Robles. 2003. Land use, land cover changes and coastal lagoon surface reduction associated with urban growth in northwest Mexico. Landscape Ecology 18:159-171.

Ruiz Luna, A., and G. de la Lanza Espino. 1999. Sistemas rurales de producción camaronicola en Guasave, Sinaloa y norte de Nayarit (descripción física, entorno y ubicación). Centro de Investigación en Alimentación y Desarrollo (Unidad Mazatlán) y Universidad Nacional Autónoma de México, Mexico City, Mexico.

Saenger, P., E. J. Hegerl, and J. D. S. Davie. 1983. Global status of mangrove ecosystems. The Environmentalist 3 (Supplement 3):1-88.

Spalding, M., F. Blasco, and C. Field. 1997. World Mangrove Atlas. International Society for Mangrove Ecosystems, Okinawa, Japan.

Stolk, M. E., 2000. Patterns of mangrove use in Hoanh Bo District, Quang Ninh Province, Northern Vietnam. Thesis, Vrije Universiteit Brussel, Brussels, Belgium.

Tack, J. F., and P. Polk. 1999. The influence of tropical catchments upon the coastal zone: modelling the links between groundwater and mangrove losses in Kenya, India and Florida. Pages 359--372 in D. Harper and T. Brown, editors. Sustainable management in tropical catchments. Wiley, London, UK.

Tam, N. F. Y., and Y. S. Wong. 1999. Mangrove soils in removing pollutants from municipal wastewater of different salinities. Journal of Environmental Quality 28:556-564.

Tomlinson, P. B. 1986. The botany of mangroves. Cambridge University Press, Cambridge, UK. 


\section{APPENDIX 1. MANGROVE QUESTIONNAIRE}

Village name GPS position

Respondent name[1]

${ }^{\circ} \longrightarrow \cdots$

$" \mathrm{~N}$

-

Date

"W

\section{Mangrove uses}

1. How many species of mangrove are you familiar with?

I

II

IV

2. Of the following, which are the most important uses of the mangrove forest resource?
a) Firewood
b) Construction
c) Fishing poles
d) Other (specify), e.g., fodder, feed, medicine, fertilizer, animal catch, insecticide, mosquito repellant (smoke)
e) None
f) Don't know

3. Which species do you use for construction?

I

II IV

4. The main type of fuel derived from mangrove forests is
a) Firewood
b) Charcoal
c) Other (specify)

5. In response to question 4 , how do you obtain this energy source?
a) Buy
b) Collect
c) Other (specify)

6. If you buy it, how frequently do you do this?
a) Every day
b) Once a week
c) Twice a week
d) Once a month
e) Twice a month 
f) Whenever necessary

7. If you cut it, how frequently do you do this?
a) Every day
b) Once a week
c) Twice a week
d) Once a month
e) Twice a month
f) Whenever necessary

8. What else do you obtain from the whole mangrove community?
a) Shrimp
b) Fish
c) Crabs
d) Molluscs
e) Birds
f) Other (specifiy)

Economic dependence on mangrove resources

1. Do you depend on the mangrove resources?
a) Yes
b) No
c) Sometimes

2. How could you meet the same needs without mangroves?
a) Look for another source of fuel energy
b) Look for another source of income
c) Migrate to another city
d) Don't know

3. If there were no other way to meet your needs, would you accept compensation?
a) Yes
b) No
c) Don't know

4. What type of compensation would be acceptable to you?
a) Money
b) Agricultural farmland
c) Free education
d) Small boat
e) Others (specify) 


\section{Mangrove evolution}

1. During the past, has their been any change in the mangrove forest resource, i.e., has it increased, decreased, or remained the same?
a) Increased
b) Decreased
c) Remained the same
d) Don't know
e) No answer
f) Don't care

2. If there has been an increase in the mangrove forest, what do you think was the main cause?
a) Less use of the mangrove forest
b) Natural events
c) Replanting
d) Enforcement of environmental protection measures
e) Other (specify)

3. If there has been a decrease in the mangrove forest, what do you think was the main cause?
a) Consumption by local people
b) Consumption by foreigners
c) Creation of new inlets by shrimp farms
d) Illegal harvesting
e) Legal harvesting
f) Diseases
g) Natural events, e.g., hurricanes
h) Tourism industry
i) Other (specify)

4. Do you expect a shortage or a continued abundance of mangroves?
a) Increase
b) Decrease
c) No change
d) Don't know
e) Don't care
f) No answer

5. Why do you believe this will happen? (open answer)

Mangrove conservation and protection

1. If mangrove resources have decreased, what can be done to counteract this? 

a) Mangrove replanting
b) Teaching conservation to villagers
c) Blocking the new farm water inlet
d) Intensifying mangrove protection
f) Other (specify)
e) Don't care

2. What, if any, type of access to the mangrove forest reserve is used?
a) Permission from the government
b) Fee
c) Free access
d) Don't know
e) No answer
f) Other (specify)

3. Do you think that land use and consumption should be prohibited in mangrove forest reserves because they are conservation areas?
a) Agree
b) Undecided
c) Disagree
d) Don't care

4. Since the inception of mangrove management protection, do you think that illegal harvesting of mangroves has decreased?
a) Yes
b) No
c) Don't know
d) No answer
e) Don't care

5. How do you think you contribute to the protection of the mangrove forest?
a) Village environmental committees
b) Permission from the government to access the mangrove forest
c) Physical
d) Other (specify)

6. If you contribute to mangrove protection, how do you do it?
a) Environmental protection committee
b) Permission from the government to have access to the mangrove resources
c) Physical contribution
d) Other (specify) 
7. To obtain a suitable area for shrimp farming, do you think it is necessary to clear-cut mangroves?
a) Yes
b) No
c) Don't know
d) No answer

8. Are there any advantages to cultivating shrimp within a mangrove forest reserve?
a) High yield
b) Less food and fertilizer needed
c) Constant water supply
d) Good water quality
e) Fewer diseases
f) Easy access
g) Other (specify)

9. Are there any disadvantages to cultivating shrimp outside the mangrove forest?
a) Low yield
b) More food and fertilizer needed
c) Unreliable water supply
d) Poor water quality
e) More diseases
f) Infertile soil
g) Other (specify)

:. Of the following, which is your main source of income?
a) Agriculture
b) Fishing
c) Aquaculture
d) Pole cutting
e) Business
f) Other (specify)

[1] Asked after completing the questionnaire. 